\title{
Microfacies analysis and depositional environments of the Middle Eocene (Bartonian) Qurn Formation along Qattamiya_Ain Sokhna district, Egypt
}

\author{
Mohamed W. Abd El-Moghny ${ }^{1}$. Atef A. Afifi
}

Accepted: 28 December 2021 / Published online: 24 February 2022

(c) The Author(s) 2022

\begin{abstract}
The exposed Middle Eocene (Bartonian) Qurn Formation along Qattamiya-Ain Sokhna district is measured, sampled and microscopically investigated. Besides, the vertical distribution of the chemical oxides and strontium ( $\mathrm{Sr}$ ) has been determined to identify their petrographic, geochemical characteristics and interpret their depositional environments. The facies analysis (lithofacies, microfacies, and biofacies) of the studied rocks revealed the recognition of three microfacies associations: (1) restricted lagoon facies association (FT1-FT3), (2) open lagoon facies association (FT4-FT7), and (3) shoal facies association (FT8-FT9). Lithofacies and microfacies analysis of Middle Eocene rocks along Qattamiya-Ain Sokhna district reflect carbonate inner ramp regime ranging from restricted lagoon to shoal buildup depositional conditions. These identified inner ramp microfacies are changed eastward to mid-ramp, while they are represented westward by tidal flat and shallow lagoonal facies. The vertical distribution of both $\mathrm{CaO}$ and $\mathrm{MgO}$ revealed that $\mathrm{MgO}$ is related mainly to the dolomitization process rather than primary deposition. The vertical distribution of $\mathrm{Sr}$ in the studied carbonate samples matches with that of $\mathrm{SiO}_{2}$, thus may be related to the warm environmental conditions.
\end{abstract}

Keywords Middle Eocene $\cdot$ Carbonates $\cdot$ Ramp $\cdot$ Microfacies $\cdot$ Environments $\cdot$ Qurn $\cdot$ Egypt

\section{Introduction}

Carbonate inner- to outer-ramps occur along the continental margin of Tethys (Santanu et al. 2018). These are dominated by larger benthic foraminifera, including nummulitid and alveolinid (Adabi et al. 2008). The studying of larger foraminifera provides crucial evidence for paleoenvironmental settings of Paleogene carbonates (Bassi et al. 2013; Hadi et al. 2016). There is a well-defined Eocene sequence extending through east Cairo in an East-West direction. The Eocene rocks in Egypt are marked by varied lithologies and depositional environments ranging from continental to lagoonal, to outer neritic conditions (Sallam et al. 2015a). The lithological complexity of these rock units and the influence of tectonic movements associated with the opening of

Mohamed W. Abd El-Moghny

m_wageeh@azhar.edu.eg

1 Present Address: Geology Department, Faculty of Science, Al-Azhar University, Nasr City, Cairo, Egypt

2 Quarry Management, Cairo Governorate, Cairo City, Egypt the Gulf of Suez had a strong bearing on its basinal depositional architecture. The Middle Eocene shallow-water carbonates in Egypt represents a Tethyan reef-rimmed carbonate platform with bedded inner-platform facies (Said 1990).

A detailed study involving microfacies and chemical characteristics of carbonates infer the depositional settings of these rock units. Facies, depositional setting, and evolution of carbonate platform of Qurn Formation remain poorly documented notwithstanding excellent outcrops. In the present work, three stratigraphic sections include Qattamiya, Abu Shama, and Ghreibun (Fig. 1), were measured, sampled, carefully investigated microscopically and chemically to identify their petrographic, geochemical characteristics and interpret their depositional environments.

\section{Methods}

Three surface sections (Fig. 1) of the Bartonian Qurn Formation are measured, sampled, and correlated along with CairoAin-Sokhna District. A total number of 45 representative samples were collected and in detail described in the field. Forty 


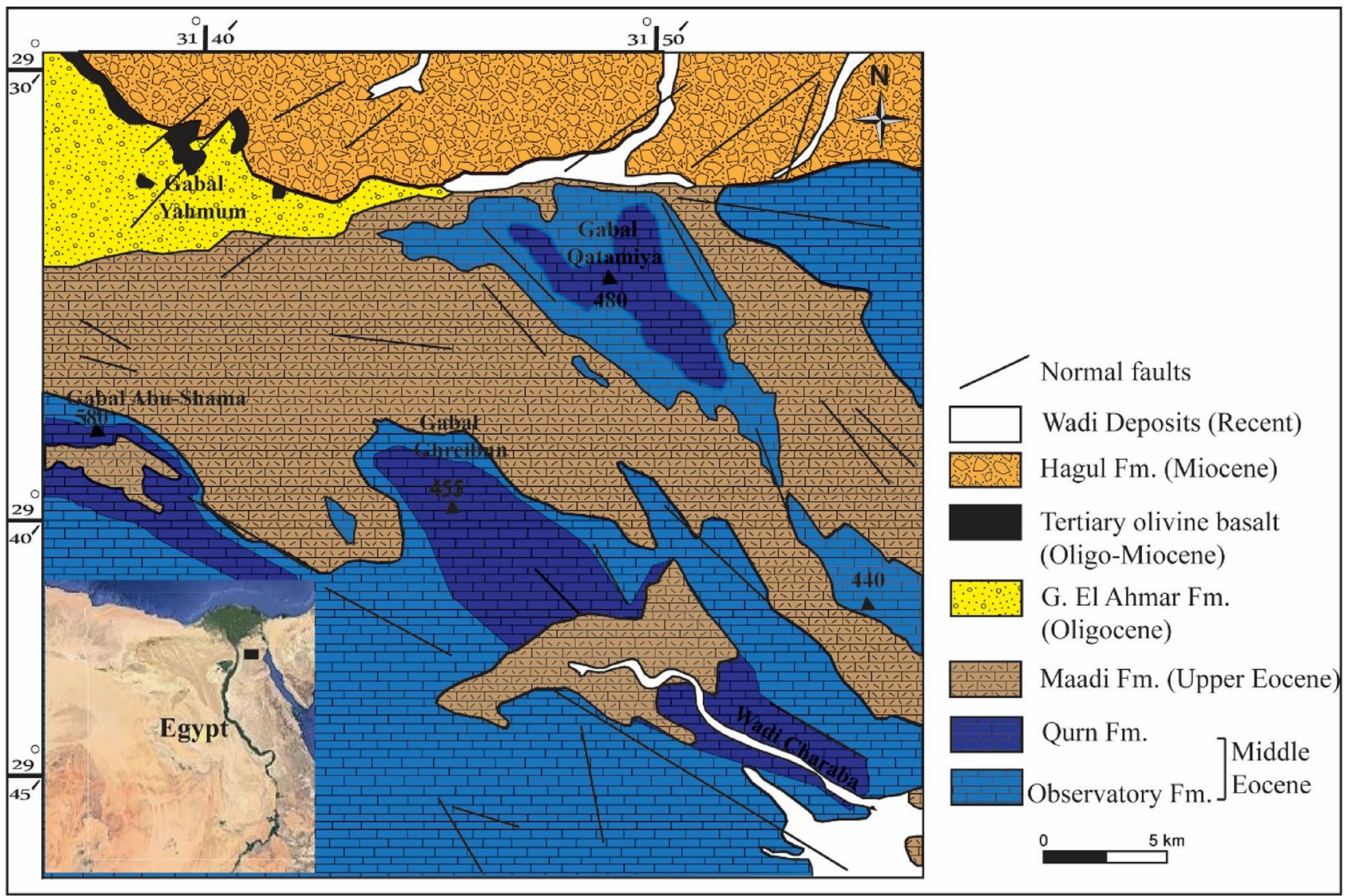

Fig. 1 Geological map of the studied area (after Conoco 1987, modified after El-Dosoky and Shahin 2020)

thin sections (12 from Qattamiya, 14 from Abu Shama, and 14 from Ghreibun) are prepared and examined for the microfacies analysis. The thin sections are investigated for the microfacies analysis, including different skeletal and non-skeletal particles, textures, grain-sizes, and cementing materials. The studied carbonate rocks were classified following the schemes of Dunham (1962), and the equivalent environments of the identified microfacies types were determined following Wilson (1975) and Flügel (2004). Besides, the faunal content of the Qurn Formation, including benthic and planktonic foraminifera, bivalves, gastropods, echinoids, and algae, was studied carefully for paleoecologic interpretations. Forty samples were selected to determine their chemical compositions and the concentration of some major oxides using X-ray fluorescence (XRF) analyses. The chemical analyses were carried out at the laboratories of Housing and Building National Research Center, Egypt.

\section{Geologic setting}

The study area occurs along Qattamiya-Ain Sokhna district $\left(29^{\circ} 35^{`}-29^{\circ} 43^{\backslash} \mathrm{E}\right.$ and $\left.31^{\circ} 35^{`}-31^{\circ} 53^{\backslash} \mathrm{N}\right)$, and exposes an Eocene sequence. It consists of carbonate and argillaceous sediments of the Middle-Upper Eocene age. These sediments were greatly influenced by the tectonic events (e.g., Suez Gulf rifting) during the early stages of the Eocene and continued to the Late Miocene (Patton et al. 1994). These events resulted in the displacement of many blocks and gave a complex stratigraphic setting on both sides of the Gulf of Suez (Steckler et al. 1988; Moustafa and Abd-Allah 1991; Issawi 2002, 2005; Osman 2003; Issawi et al. 2009; Farouk 2015). The facies change of the rock units suffer along with Cairo-Suez district area within the Eocene sections have a great impact on 
the confusion among the workers in the area (Sallam et al. 2015b).

The stratigraphy of the Eocene sediments in the Cairo-Suez district has been studied by many authors since Barron (1907). The first attempt to study the stratigraphy of the Middle Eocene rocks, east Helwan, was that of Ismail and Farag (1957), who classified the succession into five series. These series were raised later to the status of formations by Said (1962) (Table 1).

Some authors, e.g., Strougo and Abdallah (1990), Morsi (1991), Strougo et al. (1992), Abul Nasr et al. (1993), and El Safori et al. (1997) used the formational names of Helwan facies: Gebel Hof, Observatory, Qurn, Wadi Garawi, and Wadi Hof formations. Many studies were dealt with the Middle Eocene sequence of the Qattamiya-Ain Sokhna district from different aspects (e.g., Ghobrial 1971; Boukhary et al. 2002; Sallam et al. 2015b; Nasief and Korin 2018).

The Middle Eocene, Mokattam Group, in the study area is composed of sandy limestone, argillaceous siltstone facies by a thick $(112 \mathrm{~m})$ and carbonate sequence that divided into Observatory Formation, at the base, and Qurn Formations at the top. This succession is overlain by sandy limestone and argillaceous siltstone facies of Upper Eocene (Priabonian) Wadi Hof Formation (Table 1). The Observatory Formation is the oldest exposed rock unit in the studied sections. It overlies the Gebel Hof Formation of the Lutetian age and underlies the Qurn Formation of the Bartonian age. It consists of 43-48 m thick of white, chalky, hard limestone beds with thin $(30-70 \mathrm{~cm})$ hard dolomitic limestone beds in its most upper part.

The studied Qurn Formation is well developed at El Qurn and El Halawna areas (Ismail 1956) with a thickness of $97 \mathrm{~m}$ of carbonate succession that considered being of Upper Lutetian to Lower Bartonian age (Farag and Ismail 1959). Based on foraminiferal assemblages, Strougo (1985) and Strougo and Boukhary (1987) suggested a Middle Eocene age to this formation. The Qurn Formation is considered of Bartonian age by Said (1962) and Issawi et al (1999). It is also equivalent to the lower part of Tanka Formation at Gebel Tanka, West-Central Sinai (Nasief and Korin 2018).

Table 1 The stratigraphic classification of the Eocene rock units in Cairo-Suez district according to Said (1962) and Issawi et al. (1999)

\begin{tabular}{lll}
\hline $\begin{array}{l}\text { Said (1962) } \\
\text { Time unit }\end{array}$ & Issawi et al (1999) & $\begin{array}{l}\text { Rock unit } \\
\text { (formation) }\end{array}$ \\
\hline Bartonian & Priabonian & Wadi Hof \\
& Bartonian & Wadi Garawi \\
& & Qurn \\
Lutetian & Observatory \\
& Lutetian & Gebel Hof \\
\hline
\end{tabular}

Lithologically, the Qurn Formation is recorded in the studied stratigraphic sections and composed of 24-44 m thick of chalky limestone with thin argillaceous limestone beds. It overlies conformably the Observatory Formation and overlain unconformably by the upper Eocene Maadi Formation (Fig. 2). The lower part of the studied Qurn Formation is mostly composed of yellow marls and argillaceous highly fossiliferous, limestone unit (5-7 m thick), while the upper part is made up of white chalky limestone unit (up to 25 m) (Figs. 3-5). The Qurn Formation in some localities as Gebel Ghreibun forms isolated topographic heights that entirely hide the underlying Observatory Formation. Occasionally, the rocks of this studied Qurn Formation are borrowed in different scales (Fig. 2c, d).

Structurally, the studied area, as a part of the North Eastern Desert, is affected by a high number of faults. The measured sections are considered as a slightly tilted faulted block of Eocene age and are a part of E-W elongated belts of the en echelon faults along Cairo Suez district (Youssef 1968). Several fault-blocks as horst, grabens, and step faults, are bounded by several NW-oriented faults (Hagag 2016).

\section{Microfacies analysis}

Forty thin sections were investigated for the microfacies analysis that includes different skeletal and non-skeletal particles, textures, grain-sizes, and cementing materials. The microfacies classification of carbonate rocks presented in this work follows Dunham (1962) and the construction of their equivalent environments follows Wilson (1975) and Flügel (2004).

The microfacies analysis resulted in the identification of ten microfacies types grouped into three major microfacies associations as follows:

I. Restricted lagoon association microfacies

Miliolid bioclastic packstone (FT1)

Miliolid bioclastic dolomitic grainstone (FT2)

Foraminiferal bioclastic grainstone (FT3)

II. Open lagoon association microfacies

4- Molluscan bioclastic packstone (FT4)

5- Echinoidal bioclastic packstone (FT5)

6- Algal molluscan bioclastic floatstone (FT6)

7- Sandy molluscan bioclastic floatstone (FT7)

III. Shoal association microfacies

8- Sandy molluscan bioclastic grainstone (FT8)

9- Sandy echinoid bioclastic grainstone/floatstone (FT9)

The following paragraphs summarize the description and their probable depositional environments:

I. Restricted lagoon association microfacies 


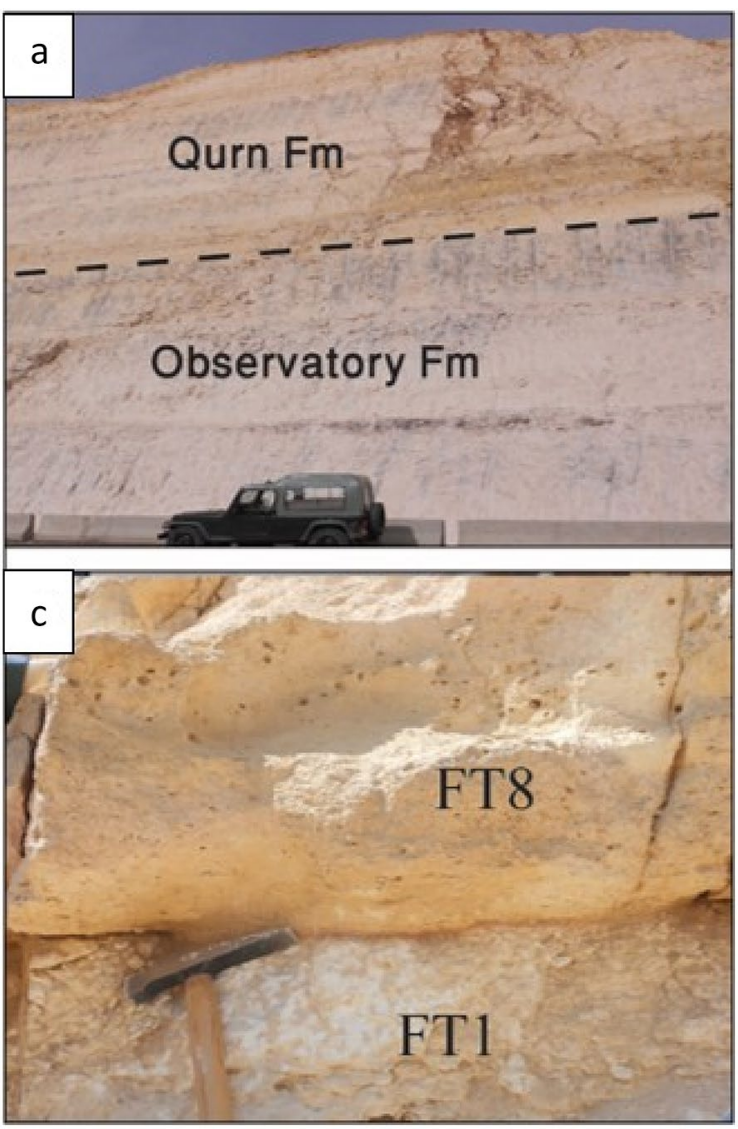

Fig. 2 Field photographs show some stratigraphic characters of the Qurn Formation: a the contact between the Qurn and its underlying Observatory formations at Abo Shama section; b the upper Eocene rocks occupy the lowlands while the studied middle Eocene Qurn

\section{Miliolid bioclastic packstone (FT1)}

This microfacies type is made up of snow-white, hard to semi-hard, fossiliferous, borrowed, limestone, and well developed in the Qurn Formation at the middle part of the Qattamiya section (Samples No.7q, 8q) and the lower parts of Abu Shama (Sample No. 1a) and Ghreibun (Samples No. 4-6 g) sections (Figs. 3, 4, 5). The allochems constitute about $30-40 \%$ of this microfacies and are represented mainly by echinoids, larger benthonic foraminifera as Miliolid (Idalina, Dictyoconus, and Fabularia) and few large Nummulite tests and molluscan (pelecypod and rare gastropod) shell fragments (Fig. 6a). Few (>2\%) planktonic foraminiferal tests are observed in this microfacies type where their spherical chambers are filled by micrite matrix and the walls are neomorphozed to crystalline calcite (Fig. 6b). Crinoid segments and spins with calcite overgrowth cement are well developed in this microfacies and their size up to $2 \mathrm{~mm}$. The foraminiferal tests are filled by recrystallized spary calcite. Molluscan bioclastic
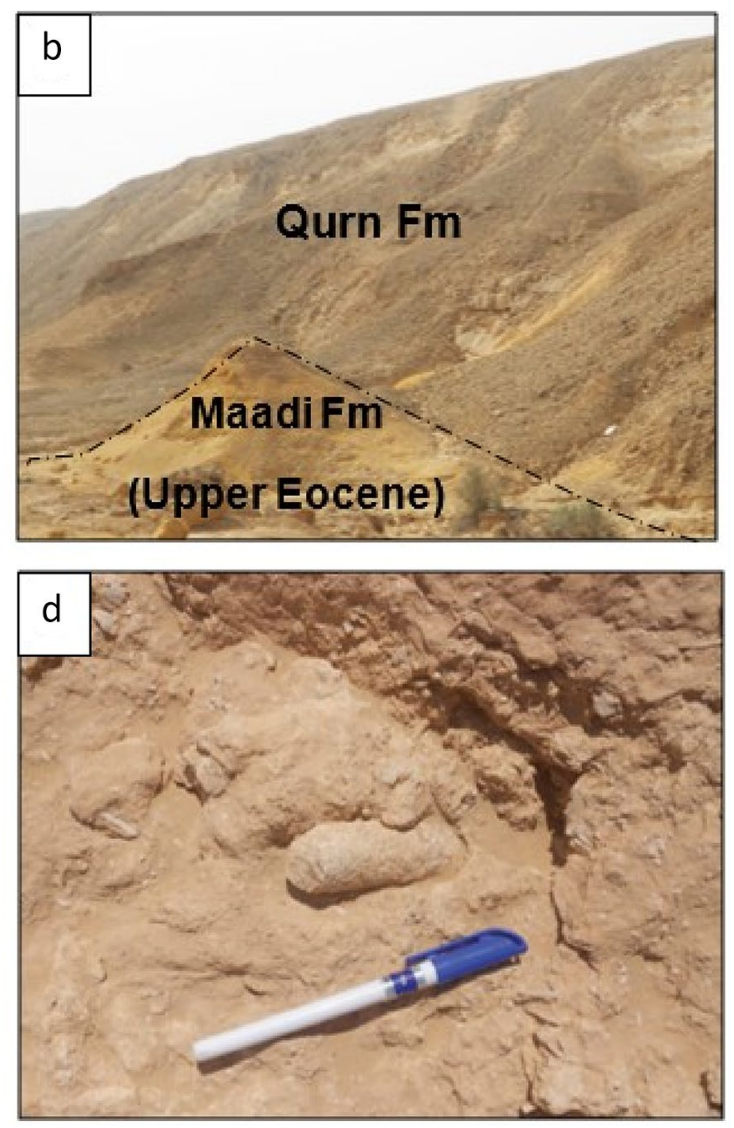

Fm. at the high land at Ghreibun section; c sharp contact between snow-white limestone (FT1 and borrowed limestone (FT8) at Ghreibun section; $\mathbf{d}$ borrows that common in the Qurn Formation at Ghreibun section

grains are partially or entirely recrystallized into mosaic macrocrystalline calcite. Biological bioturbation is well developed in this rock type and represented by borrows which are filled by very fine quartz and carbonate matrix (Fig. 6c). The bioclastic grains are embedded in the cryptocrystalline calcite matrix (about 60\%), which is partially recrystallized forming spary calcite patches.

\section{Interpretation}

The enrichment of calcite matrix and the faunal content as Miliolid, bivalve, echinoids and biological borrowing reflect a quiet, shallow subtidal, open marine platform of this microfacies (Flügel 1982). Shallow nearshore and lagoonal environments, down to about $50 \mathrm{~m}$, are characterized by porcelaneous miliolid foraminifera. Planktonic foraminifera are absent or rare in shallow-marine environments (Flügel 2004). 


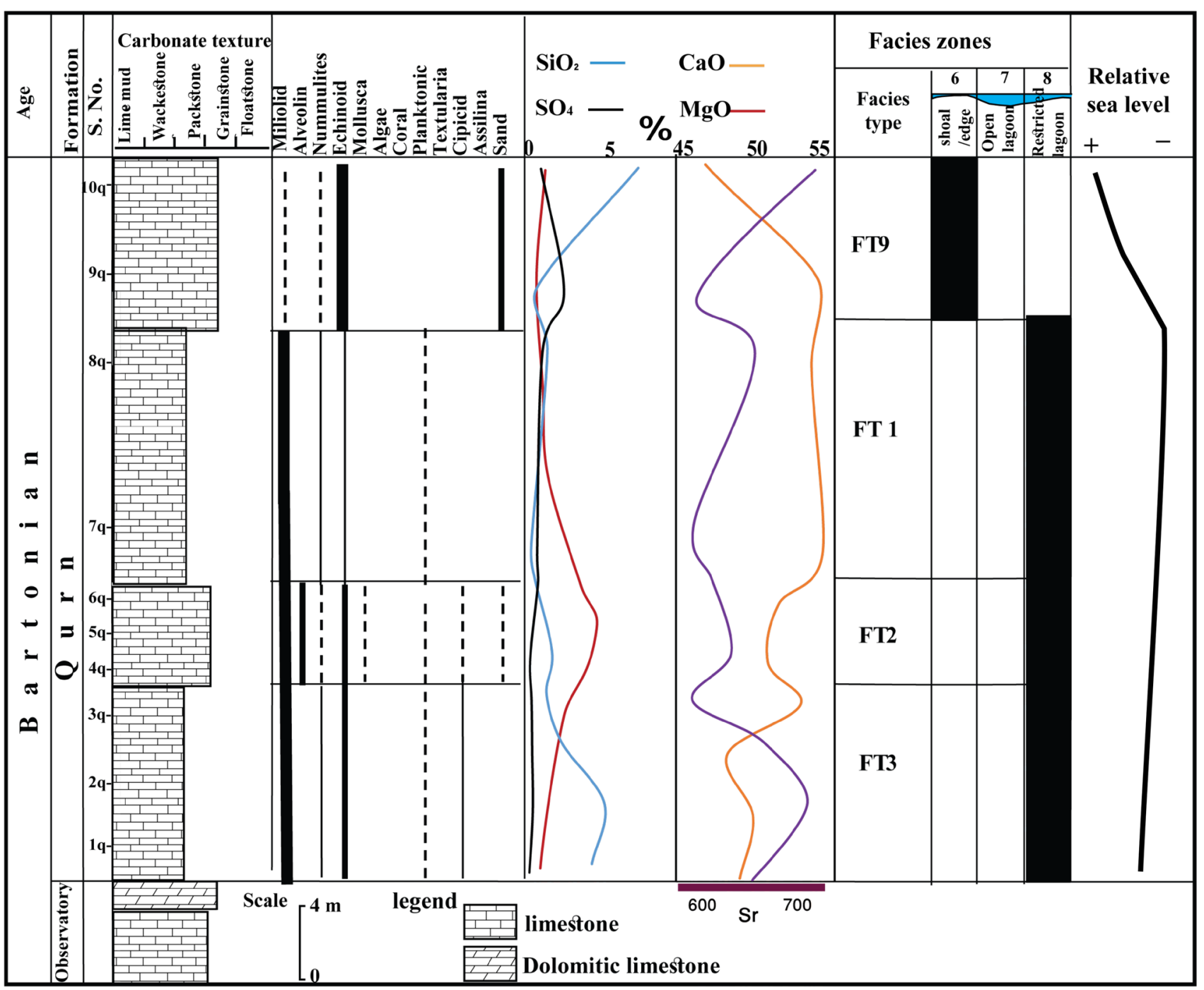

Fig. 3 Stratigraphic column of Qattamiya section showing microfacies types, texture, vertical distribution of some major oxides and depositional environment

\section{Miliolid bioclastic dolomitic grainstone (FT2)}

This microfacies type is recorded in the lower part of the Qurn Formation at measured Qattamiya section (Samples No. 4-6q) and upper part of Ghreibun (Samples No. $23 \mathrm{~g}$, $24 \mathrm{~g}$ ) (Figs. 3, 5). It consists of yellow to yellowish-white, massive, very hard, fossiliferous, very hard, dolomitic limestone. Allochems in this microfacies, constitute about $50 \%$ of the rock, are represented by benthonic foraminifera (miliolid), echinoid as well as less than $<5 \%$ bivalve fragments. Echinoid fragments range in their size from 0.5 to $3 \mathrm{~mm}$ and are characterized by syntaxial overgrowth calcite cement. On the other hand, foraminiferal tests are filled with sparite cement and their walls are mostly micritized. Bivalve shell fragments are composed of fibrous crystalline calcite. Allochems are embedded in microcrystalline spray calcite (up to $45 \%$ ) with relics of micrite matrix (20\% of the rock) that reflect a neomorphism diagenetic process of micrite matrix to form spray calcite (Fig. 6d). On large scale, the groundmass spray calcite is dolomitized forming planarsubhedral (hypidotopic to xenotopic) textures with subhedral to anhedral dolomite crystals that have straight boundaries and crystal-face junctions. It is worth to mention that, zoned dolomitic rhombs are recorded, although with fewer ratios, in this microfacies (Fig. 6d).

\section{Interpretation}

The association of both cryptocrystalline and microcrystalline calcite as well as the faunal content, specially Miliolid, and its diversity indicate its deposition in slightly agitated, restricted, shallow lagoonal environment (Sallam et al. 


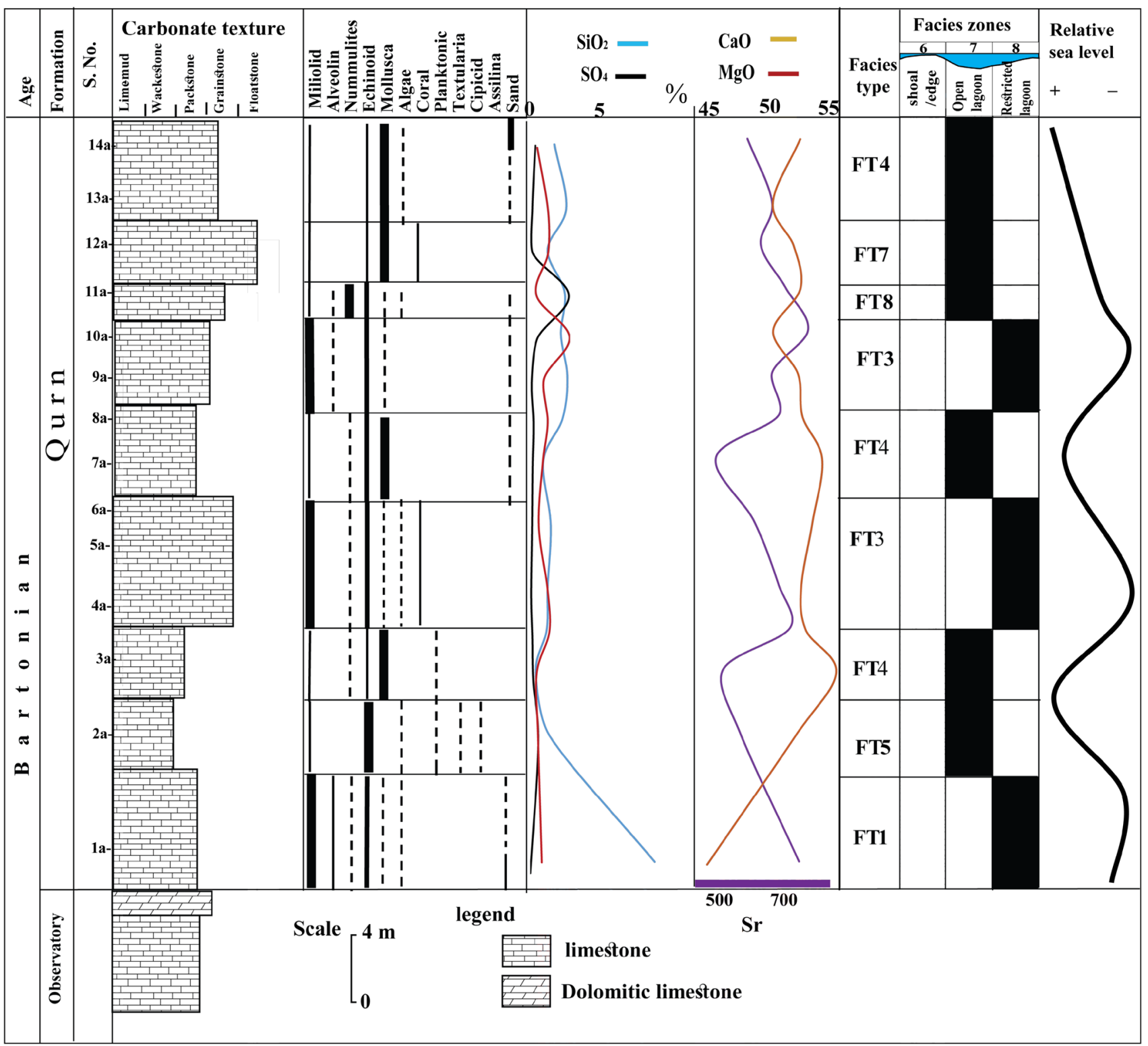

Fig. 4 Stratigraphic column of Abu Shama section showing microfacies types, texture, vertical distribution of some major oxides and depositional environment

2015a). This microfacies type can be compared with SMF 18-FOR of Flügel (2004), where the Miliolid foraminifera are very common in lagoonal environments (sometimes with elevated salinity) of Mesozoic and Cenozoic restricted inner platforms and inner ramps.

\section{Miliolid bioclastic grainstone (FT3)}

This microfacies occurs in the lower part of Qurn Formation at Qattamiya section (samples no. 1-3q) and several intervals of Abu Shama section (samples No., 4-6a, 9a, 10a) (Figs. 3, 4). It is composed of white, hard, compact, highly fossiliferous, chalky limestone. Petrographically, the allochems of this microfacies type form about $70 \%$ of the rock and are represented mainly by moderately sorted, highly diverse foraminiferal content, as miliolid, Nиттиlites, cipicid, and rare planktonics, as well as crinoids and trace $(<5 \%)$ bivalves shell fragments. The chambers of foraminiferal tests are filled with sparite cement and their walls are composed of micrite (Fig. 6e). Occasionally, the original structure of the foraminiferal tests is poorly preserved as a result of its complete micritization. Bivalve shell fragments are made up of fibrous calcite. Echinoid fragments are completely recrystallized with overgrowth calcite cement (Fig. 6f). These allochems are bounded by macrocrystalline calcite cement which constitutes up to $30 \%$ of the rock. 


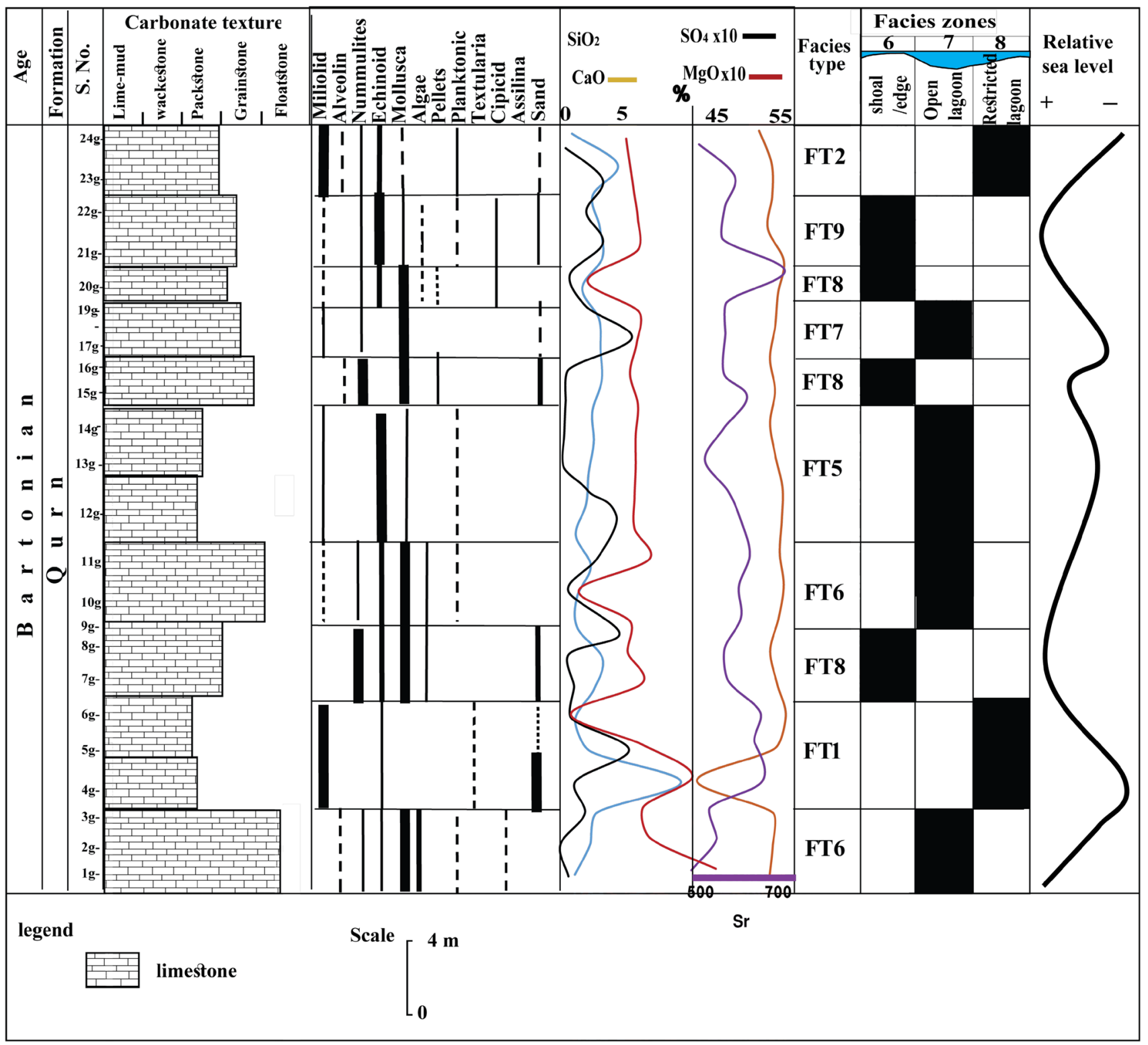

Fig. 5 Stratigraphic column of Ghreibun section showing microfacies types, texture, vertical distribution of some major oxides and depositional environment

\section{Interpretation}

The moderately sorting texture of the well preserved bioclastic allochems and the coarse-grained sparry calcite groundmass, as well as some miliolidae are filled with sparite revealed the deposition of this microfacies type in a shallow marine, more restricted sheltered lagoon environment (Sallam et al. 2015b).

II. Open lagoon association microfacies

\section{Molluscan bioclastic packstone (FT4)}

This microfacies type is recorded in the middle and upper parts of the Qurn Formation at Abu Shama section (Samples No. 3a, 7a,,8a \& 13a, 14a, respectively) (Fig. 4). It is composed essentially of yellowish-white, hard, fossiliferous borrowed limestone. Petrographically, it is made up mostly of dense cryptocrystalline calcite matrix (micrite) that forming about $60 \%$ of the microfacies with bivalve and foraminiferal shell fragments that are embedded in micrite 


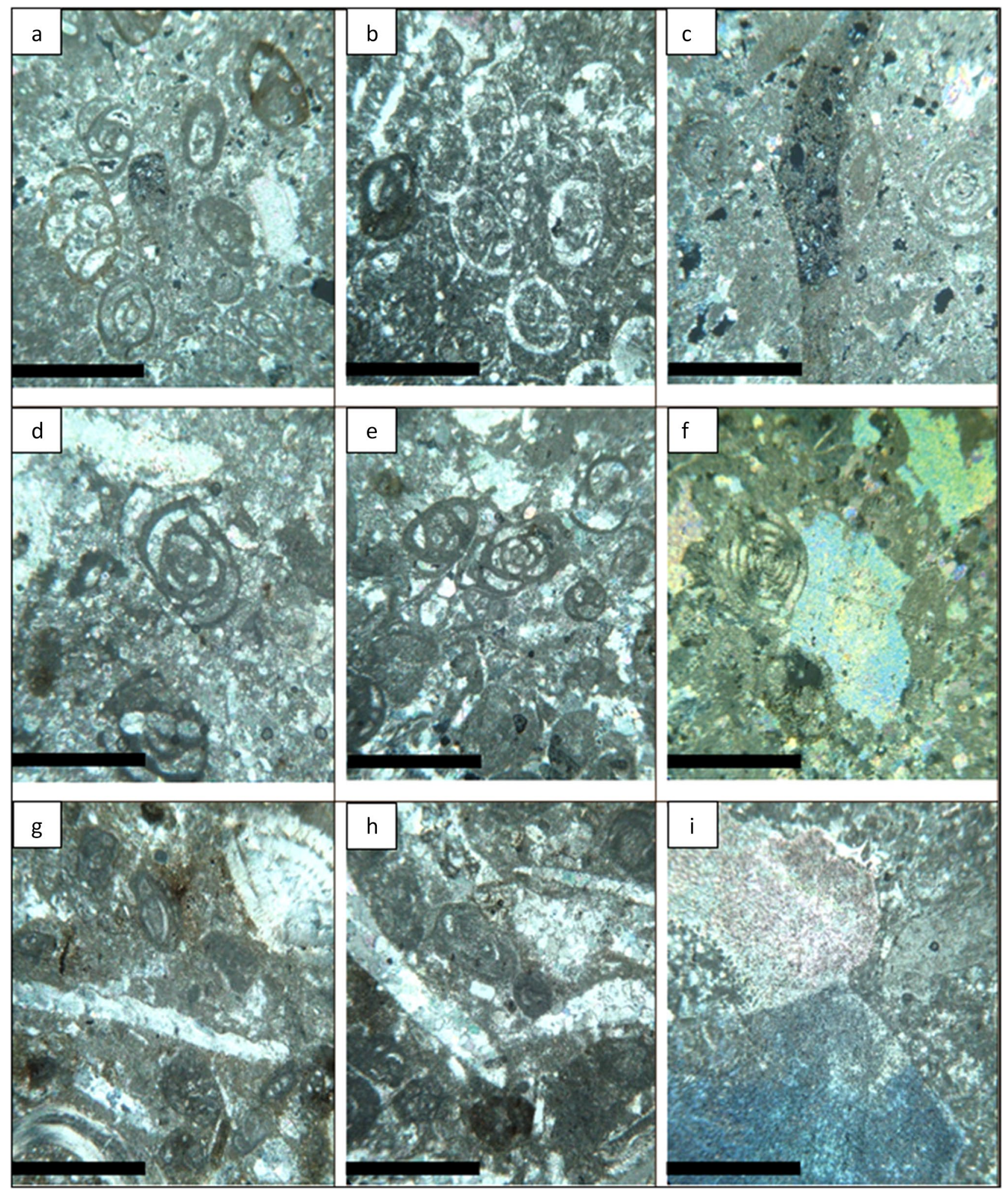

Fig. 6 Photomicrographs show different microfacies types in Qurn Formation along Cairo-Ain Sokhna district: $\mathbf{a}, \mathbf{b}, \mathbf{c}$ Miliolids bioclastic packstone (FT1) with enrichment of miliolids tests in a, spherical chambers of planktonic foraminifera in $\mathbf{b}$, and the borrow is filled by very fine quartz and carbonate matrix in $\mathbf{c} ; \mathbf{d}, \mathbf{e}, \mathbf{f}$ Miliolids bioclastic dolomitic grainstone (FT2) in which the fine dolomite crystals can be observed in the central part of $\mathbf{d}$, and the foraminiferal tests are filled by sparit in $\mathbf{e}$, the echinoid fragments with their diagnostic overgrowth cement texture in $\mathbf{f} ; \mathbf{g}, \mathbf{h}$ Miliolids Bioclastic grainstone (FT3), note the presence of nummulite test in the uppermost part of $(6 \mathrm{~g})$ and poor preserved miliolids tests in $\mathbf{h}$ Bare scale $=250 \mu \mathrm{m}$ 
matrix (Fig. 6g). Molluscan fragments are sized from 2 to $0.5 \mathrm{~mm}$ and recrystallized into fibrous and macrocrystalline calcite. Foraminiferal tests, mainly benthic forms, are poorly preserved and filled by crystalline calcite (Fig. 6h). Echinoid fragments also can be recorded with overgrowth calcite cement as a diagnostic feature. Biological borrowing well developed in this facies type and these pores were filled by fine carbonate and quartz grains. In addition to the above-mentioned components, ca. $4 \%$ iron oxide patches are scattered within the calcite matrix.

\section{Interpretation}

Based on the enrichment of dense micrite matrix, faunal content, and biological borrowing, this microfacies can be comparable to the facies zone (FZ8) of Wilson (1975) and this microfacies type is deposited in a quite open carbonate platform, shallow lagoonal environment below fair-weather wave base with low circulation conditions.

\section{Echinoidal bioclastic packstone (FT5)}

This microfacies type is recorded in the lower part of the Qurn Formation at Abu Shama section (Sample No. 2a) and the middle part of the Ghreibun section (Samples No. 12-13 g). It is composed of snow-white, chalky, semi-hard, fossiliferous limestone. The allochems constitute up to $30 \%$ of this microfacies and are represented by crinoids, pelecypod, miliolid, and planktonic foraminifera. Echinoids are well developed in this microfacies as spins and stem fragments and characterized by calcite overgrowth cement (Fig. 6i). Benthonic foraminiferal tests of five different forms can be noted where they are filled by crystalline calcite and their walls are micritized. Less than 5\% of fine to very fine quartz grains can be observed in this microfacies. The bioclastic grains are slightly badly preserved and cemented by crypto/microcrystalline calcite matrix (up to $80 \%$ ).

\section{Interpretation}

This microfacies type is characterized by enrichment of micrite matrix and faunal diversity. Some of this micrite are partly neomorphosed into microspars filling the intergranular spaces. This microfacies type can be deposited in the shelf open lagoon of low-energy environment in quiet water below wave base with normal salinity, oxygenated water conditions, and good current circulation. Water depth is tens of meters (Sallam et al. 2015b). This microfacies type can be correlated with RMF (7) that of deposited in protected and low-energy inner ramp environments. A common microfacies type in these environments is characterized by common to abundant echinoderm fragments and associate skeletal grains, occurring in different quantity are bivalve shells, gastropods, bryozoans, and benthic foraminifera (Flügel 2004).

\section{Algal molluscan bioclastic floatstone (FT6)}

These carbonate facies is recorded in the lower and middle parts of the Qurn Formation at the Ghreibun section (Samples No. 1-3 g and 10-11 g, respectively) (Fig. 5). It is composed of yellowish-white, hard, fossiliferous limestone. Bioclastic grains of this microfacies form about $40 \%$ of the rock and are represented by moderately sorted large molluscan, echinoid, Nummulites, and rare benthonic foraminiferal, bryozoan, and algal fragments (Fig. 7a). About one-fifth of the bioclastic grains are of remarkable large size $(>2 \mathrm{~mm})$. The size of molluscan fragments ranges from 0.5 to $4 \mathrm{~mm}$ and their main size is $3 \mathrm{~mm}$. Bivalve shell fragments are composed of radial and/or mosaic macrocrystalline calcite (Fig. 7b). Foraminiferal tests, Nummulites, and miliolid, are filled by sparite cement while their walls are made up of cryptocrystalline calcite. Nummulitic fragments increase upward of the Gharbiun section. Algae are represented by green types with original structures and their grains are filled by micrite. All components are embedded in a micrite matrix that composes up to $60 \%$ of the rock. The calcite matrix is partially recrystallized into spary calcite cement.

\section{Interpretation}

This microfacies type can be compared by the open inner ramp microfacies type (RMF15) that introduced by Flügel (2004). It mainly consists of bioclastic floatstone with various reef-derived material (near-reef coral-, algal- or bivalve-debris). The identified faunal content and enrichment of moderately sorted, coarse bioclastic grains, as well as micrite matrix reflect quite, open lagoon depositional environment.

\section{Sandy molluscan bioclastic floatstone (FT7)}

This carbonate facies is recorded in the Qurn Formation at both Abu Shama and Ghreibun sections (Samples No. 11-12a and 13-14 g \& 17-19 g, respectively) (Figs. 4, 5). It is composed of yellowish-white, hard, massive, fossiliferous limestone. Petrographically, allochems of this microfacies form about $57 \%$ of the rock and are represented by illsorted large molluscan, larger foraminifera (Nummulites and miliolid), pellets, and echinoid fragments. Occasionally, the increasing of Nummulite fragments can be detected downward in this microfacies (sample 11a). Bivalve bioclastic grains are of remarkable large size (up to $5 \mathrm{~mm}$ ). The size of molluscan fragments ranges from 0.25 to $5 \mathrm{~mm}$ and their main size is $3 \mathrm{~mm}$. Bivalve shell fragments are composed of mosaic macrocrystalline calcite and in few cases of radial 

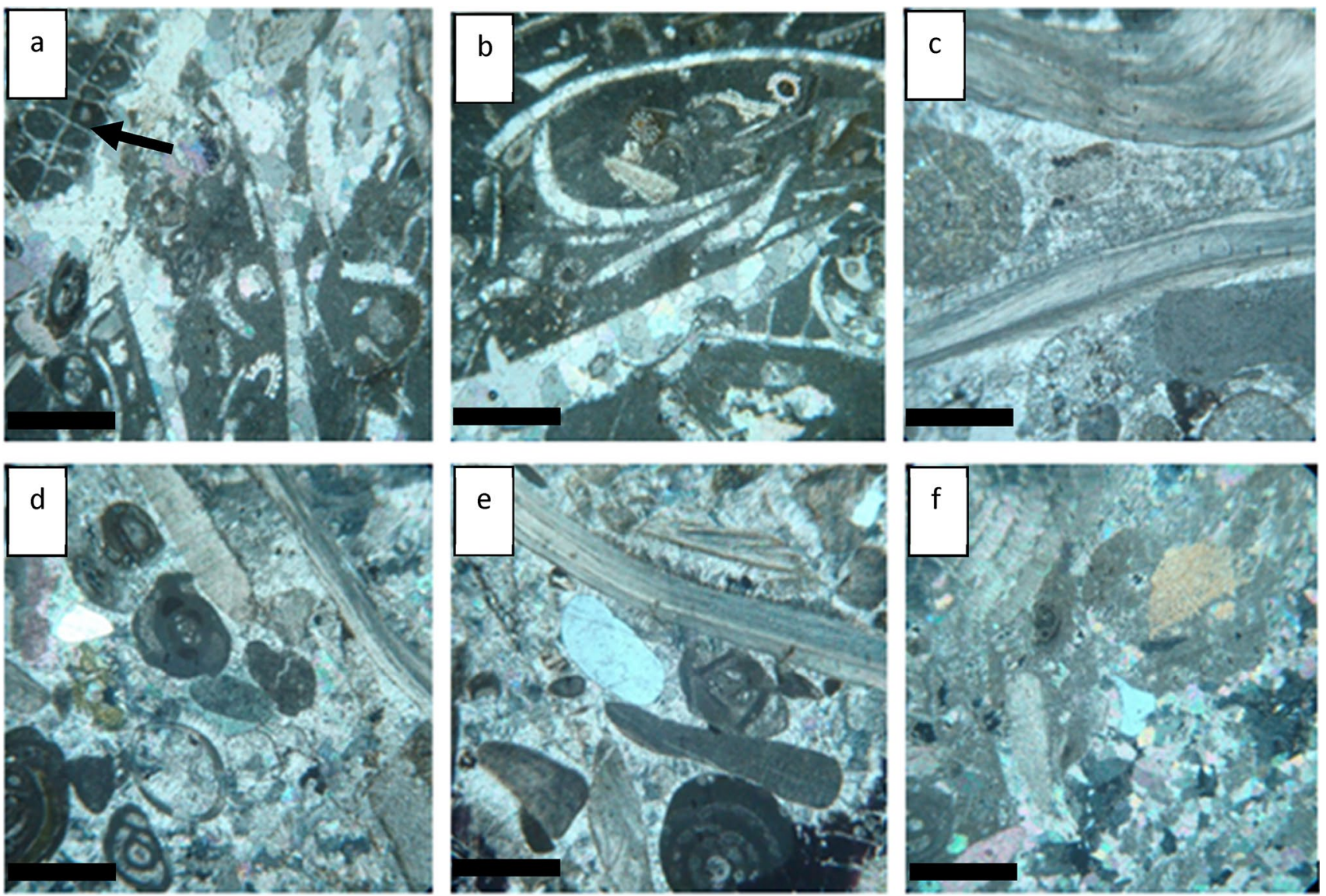

Fig. 7 Photomicrographs show different microfacies types in Qurn Formation along Cairo- Ain Sokhna district: a, b, c Algal Molluscan bioclastic floatstone (FT6) with large molluscan fragments ( $>2 \mathrm{~mm}$ ), note the green algae fragments (arrow) in $\mathbf{a}$, and the molluscan shell fragments are recrystallized into coarse mosaic calcite in (b); (c)

calcite (Fig. 7c). Foraminiferal tests, benthonic and planktonic forams are filled by sparite cement while their walls are made up of cryptocrystalline calcite. Some gastropod shell fragments can be noted and act as a trap of different grains. Fine to medium sand, well-sorted, angular quartz grains can be noted $(<5 \%)$ in this microfacies. Traces of gypsum microcrystals can be pointed out in grayish-white, fibrous texture. All components are embedded in a micrite matrix that composes up to $40 \%$ of the rock. The calcite matrix is partially recrystallized into spary calcite cement.

\section{Interpretation}

The presence of coarse-grained molluscan and nummulites fragments, quartz grains, pellets as well as the enrichment of micrite matrix reveals a slightly quite, open lagoon, mostly back-shoal, depositional environment. The abnormal abundance of certain bivalves, such as oysters, may form reef-like structures (Tucker 2001).
Sandy molluscan bioclastic floatstone (FT7); d, e Sandy molluscan bioclastic grainstone (FT8) with few yellowish-green glauconitic grains in $\mathbf{d}$ and coarse quartz grains in $\mathbf{e} ; \mathbf{f}$ Sandy echinoid bioclastic grainstone (FT9) with coarse echinoid grains and fine to very fine quartz grains. Bare scale $=250 \mu \mathrm{m}$

\section{Shoal association microfacies}

\section{Sandy molluscan bioclastic grainstone (FT8)}

This microfacies is recorded in the Qurn Formation at several levels of the Ghreibun section (Samples No. 7-9 g, 15-16 g, and $20 \mathrm{~g}$ ) and composed of white, semi-hard, compact, fossiliferous, borrowed limestone (Fig. 5). Allochems compose about $60 \%$ of this microfacies and are represented by bivalve, echinoids, pellets, different forms of foraminiferal tests (mainly Nummulites with rare Miliolid), as well as less than $5 \%$ of green algae fragments (Fig. 7d). Molluscan shell fragments are recrystallized and transformed into macrocrystalline calcite (Fig. 7e). The foraminiferal tests are filled with sparite and their walls are mostly made up of micrite. Few echinoid segments, with characteristic calcite overgrowth cement, are rarely recorded. Additionally, well-sorted, angular, and fine to medium-sized quartz grains can be noted (up to $10 \%$ ) in this microfacies. Very 
fine yellowish-green glauconitic pellets are recorded in this microfacies (Fig. 7d). All the above-mentioned components are embedded in macrocrystalline calcite cement.

\section{Interpretation}

The faunal content as well as enrichment of crystalline calcite cement and quartz grains in this microfacies revealed its deposition in sand shoal environment with slightly effect of siliciclastic influx from near land (Wanas 2008). This microfacies can compared with the sediments of FZ6 (Wilson 1975) and RMF27 of Flügel (2004) that are characterized by abundance of pellets, bivalve, algae, and quartz grains.

\section{Sandy echinoid bioclastic grainstone/floatstone (FT9)}

This microfacies, occurs in the Qurn Formation at the upper part of the studied Qattamiya and Ghreibun sections (Samples No. 9-10q and 21-22 g, respectively) (Figs. 3, 5). It consists of yellowish-white, very hard, compact, fossiliferous, argillaceous limestone. Bioclastic grains of this microfacies constitute about $42 \%$ of the rock and are represented mainly by echinoid segments of different sizes-up to $2.5 \mathrm{~mm}$ which are characterized by calcite overgrowth cement. Additionally, other constituents $(\leq 5 \%)$ of the bioclastic grains are benthonic foraminifera, of various forms, and bivalve shell fragments that can be recorded and made up of fibrous crystalline calcite. Besides the bioclastic elements, quartz grains, forming up to $15 \%$ of the rock, are composed mainly of moderately sorted, angular, oval to subspherical, monocrystalline, medium to fine sand grains with oblique extinction (Fig. 7f). All grains are embedded in crystalline calcite cement, sparite, which constitutes up to $55 \%$ of the rock.

\section{Interpretation}

The enrichment of very coarse echinoid segments, macrocrystalline calcite and moderately sorted quartz grains reflect the deposition of this microfacies in shoal environment. In modern seas, echinoids inhabit reef and associated environments (Tucker 2001). This microfacies type can be correlated with RMF 26 that represent a type of Carbonate sand shoals and banks microfacies and characterized by coarse-grained bioclastic grainstones with various benthonic skeletal grains (Flügel 2004).

\section{Geochemistry}

The Qurn Formation at the three investigated stratigraphic sections (Qattamiya, Abu Shama, and Ghreibun) is mainly composed of carbonate rocks. These rocks are chemically analyzed (Table 2) to detect the vertical variation in their chemical composition. The vertical variation diagram of the major elements component of this formation at the studied sections (Figs. 3, 4, 5) shows that the $\mathrm{SiO}_{2}$ variation curve is consistent with some deviation from $\mathrm{Al}_{2} \mathrm{O}_{3}$ and $\mathrm{Fe}_{2} \mathrm{O}_{3}$ while the inter-element relationship $\mathrm{CaO}$ shows that a negative reversible relationship with both $\mathrm{SiO}_{2}$ and $\mathrm{MgO}$. The variation curves of $\mathrm{CaO}$ and $\mathrm{MgO}$ are mostly inconsistent with each other.

The identified microfacies types (FT1, FT2, and FT3) are characterized by enrichment of $\mathrm{SiO}_{2}, \mathrm{Na}_{2} \mathrm{O}, \mathrm{Cl}, \mathrm{K}_{2} \mathrm{O}$, and Sr. The studied open lagoon microfacies (FT4, FT5, FT6, and FT7) have high concentration of $\mathrm{CaO}$ (up to $55.1 \%$ ) with slightly decreasing in $\mathrm{Na}_{2} \mathrm{O}, \mathrm{Cl}$, and $\mathrm{Sr}$ content. The detected shoal microfacies are characterized by high concentration of calcium and silicon oxides and occasionally the sodium oxide is slightly high concentrated $(0.94 \%)$ as in the Qattamiya section (Sample No. 10q). The microfacies at the uppermost parts of the studied Qattamiya and Ghreibun sections (FT9 and FT2, respectively) are characterized by high $\mathrm{Fe}_{2} \mathrm{O}_{3}$ concentration.

\section{Discussion}

The carbonate rocks of the Qurn Formation at Qattamiya section are characterized by enrichment of miliolid foraminiferal tests that occasionally associated with, echinoids, and larger foraminiferal tests of nummulites (FT1, FT2, FT3). This faunal assemblage is depleted in the upper part of this stratigraphic section and replaced by echinoid fragments as well as sand-quartz grains. The presence of miliolid in great quantities reveals the restricted inner ramp depositional environment (Fig. 8). The predominance of mud-rich lithology with miliolid, as well as the presence of a low-diversity foraminiferal association indicates a shallow restricted lagoonal environment with low energy (Vaziri-Moghaddam et al. 2006; Wanas 2008). Besides, the main carbonate texture of this stratigraphic section is the packstone and reflects quite marine depositional conditions (Tucker 2001). The nummulites accumulation forms in a broad range of water depths in inner and mid-ramp within the photic zone (Gilham and Bristow 1998; Racey et al. 2001) and they are absent in restricted marine environments (Adabi et al. 2008). Larger benthic foraminifera with relatively thinner tests like that of Assilina is common either in less transparent waters (Hottinger 1997) or in deeper waters with low light intensity (Santanu et al. 2018).

As mentioned above, the upper part of the Qattamiya section is made up of carbonates with echinoid and quartz grains with grainstone texture (FT9) that reflect a sandy shoal depositional environments. These rich-miliolid packstone and grainstone microfacies types are similar to SMF 
Table 2 Chemical concentration of some major oxides (\%) and strontium (ppm) in the studied Eocene rocks

\begin{tabular}{|c|c|c|c|c|c|c|c|c|c|c|c|c|c|}
\hline Section & $\begin{array}{l}\text { Oxide } \\
(\%) \\
\text { Sample No }\end{array}$ & $\mathrm{SiO}_{2}$ & $\mathrm{Al}_{2} \mathrm{O}_{3}$ & $\mathrm{Fe}_{2} \mathrm{O}_{3}$ & $\mathrm{CaO}$ & $\mathrm{MgO}$ & $\mathrm{SO}_{4}$ & $\mathrm{~K}_{2} \mathrm{O}$ & $\mathrm{Na}_{2} \mathrm{O}$ & $\mathrm{Cl}^{-}$ & L.O.I & $\begin{array}{l}\mathrm{Sr} \\
(\mathrm{ppm})\end{array}$ & $\begin{array}{l}\text { Total } \\
(\%)\end{array}$ \\
\hline \multirow[t]{25}{*}{ Ghreibun } & 24 & 4.43 & 0.16 & 1.21 & 51.4 & 0.73 & 0.06 & 0.02 & 0.04 & 0.04 & 41.11 & 510 & 99.22 \\
\hline & 23 & 2.01 & 0.08 & 1.17 & 53.3 & 0.76 & 0.33 & 0.03 & 0.38 & 0.35 & 41.50 & 692 & 99.88 \\
\hline & 22 & 2.67 & 0.09 & 0.72 & 53.4 & 0.80 & 0.21 & 0.04 & 0.11 & 0.05 & 41.02 & 642 & 99.08 \\
\hline & 21 & 2.97 & 0.02 & 0.62 & 52.7 & 0.80 & 0.33 & 0.04 & 0.05 & 0.04 & 42.28 & 632 & 99.86 \\
\hline & 20 & 1.00 & 0.31 & 0.47 & 55.1 & 0.35 & 0.09 & 0.02 & 0.08 & 0.04 & 42.33 & 950 & 99.82 \\
\hline & 19 & 2.62 & 0.70 & 0.40 & 54.8 & 0.81 & 0.21 & 0.03 & 0.05 & 0.04 & 40.26 & 651 & 99.39 \\
\hline & 18 & 2.78 & 0.19 & 0.38 & 53.8 & 0.79 & 0.54 & 0.04 & 0.07 & 0.05 & 41.20 & 645 & 99.88 \\
\hline & 17 & 2.88 & 0.15 & 0.22 & 53.1 & 0.73 & 0.08 & 0.02 & 0.05 & 0.05 & 42.33 & 638 & 99.54 \\
\hline & 16 & 1.98 & 0.11 & 0.17 & 53.8 & 0.80 & 0.06 & 0.02 & 0.04 & 0.04 & 42.51 & 756 & 99.53 \\
\hline & 15 & 2.11 & 0.26 & 0.13 & 53.1 & 0.78 & 0.05 & 0.01 & 0.07 & 0.07 & 43.29 & 636 & 99.82 \\
\hline & 14 & 1.62 & 0.12 & 0.15 & 53.9 & 0.78 & 0.04 & 0.02 & 0.04 & 0.03 & 43.12 & 540 & 99.78 \\
\hline & 13 & 1.38 & 0.06 & 0.30 & 54.9 & 0.77 & 0.12 & 0.04 & 0.08 & 0.06 & 42.10 & 660 & 99.85 \\
\hline & 12 & 0.37 & 0.13 & 0.10 & 54.8 & 0.77 & 0.40 & 0.01 & 0.08 & 0.07 & 43.11 & 730 & 99.86 \\
\hline & 11 & 1.83 & 0.08 & 0.26 & 54.5 & 0.90 & 0.28 & 0.05 & 0.09 & 0.06 & 41.61 & 770 & 99.69 \\
\hline & 10 & 0.49 & 0.19 & 0.10 & 55.1 & 0.27 & 0.08 & 0.01 & 0.09 & 0.06 & 43.48 & 715 & 99.88 \\
\hline & 9 & 0.51 & 0.01 & 0.09 & 54.4 & 0.73 & 0.45 & 0.01 & 0.07 & 0.06 & 42.50 & 725 & 98.79 \\
\hline & 8 & 2.97 & 0.04 & 0.20 & 53.1 & 0.71 & 0.08 & 0.05 & 0.04 & 0.04 & 42.12 & 640 & 99.32 \\
\hline & 7 & 2.13 & 0.07 & 0.33 & 54.1 & 0.84 & 0.12 & 0.05 & 0.13 & 0.12 & 41.50 & 660 & 99.39 \\
\hline & 6 & 0.30 & 0.12 & 0.04 & 55.4 & 0.20 & 0.10 & 0.01 & 0.07 & 0.05 & 43.61 & 825 & 99.92 \\
\hline & 5 & 1.77 & 0.13 & 0.38 & 53.8 & 0.85 & 0.52 & 0.08 & 0.19 & 0.18 & 42.02 & 798 & 99.97 \\
\hline & 4 & 10.6 & 2.53 & 1.58 & 42.1 & 1.29 & 0.13 & 0.31 & 1.23 & 1.10 & 39.10 & 850 & 99.92 \\
\hline & 3 & 2.38 & 0.24 & 0.50 & 53.5 & 0.85 & 0.20 & 0.06 & 0.26 & 0.21 & 41.50 & 567 & 99.72 \\
\hline & 2 & 1.79 & 0.28 & 0.06 & 53.5 & 0.91 & 0.02 & 0.01 & 0.06 & 0.05 & 43.20 & 600 & 99.83 \\
\hline & 1 & 0.28 & 0.11 & 0.14 & 52.9 & 1.50 & 0.08 & 0.01 & 0.06 & 0.01 & 43.42 & 470 & 98.55 \\
\hline & Average & 2.24 & 0.25 & 0.40 & 53.3 & 0.78 & 0.19 & 0.16 & 0.14 & 0.11 & 42.09 & 679.1 & 99.60 \\
\hline \multirow[t]{15}{*}{ Abu Shama } & 14 & 1.78 & 0.51 & 0.27 & 52.9 & 0.28 & 0.17 & 0.03 & 0.24 & 0.10 & 43.00 & 615 & 99.23 \\
\hline & 13 & 2.66 & 0.97 & 0.91 & 51.1 & 0.85 & 0.07 & 0.05 & 0.26 & 0.22 & 42.75 & 670 & 99.84 \\
\hline & 12 & 1.27 & 0.79 & 0.37 & 52.4 & 0.85 & 0.08 & 0.01 & 0.15 & 0.09 & 43.12 & 645 & 99.17 \\
\hline & 11 & 2.54 & 0.16 & 0.44 & 52.9 & 0.23 & 1.30 & 0.01 & 0.08 & 0.05 & 42.18 & 700 & 99.85 \\
\hline & 10 & 2.26 & 0.40 & 0.36 & 51.1 & 1.98 & 0.24 & 0.03 & 0.22 & 0.11 & 43.10 & 750 & 99.82 \\
\hline & 9 & 2.74 & 0.51 & 0.25 & 52.7 & 0.63 & 0.05 & 0.08 & 0.17 & 0.05 & 42.71 & 670 & 99.90 \\
\hline & 8 & 2.38 & 0.75 & 0.51 & 53 & 0.83 & 0.11 & 0.05 & 0.31 & 0.21 & 41.81 & 685 & 99.95 \\
\hline & 7 & 0.95 & 0.52 & 0.19 & 54.3 & 0.57 & 0.08 & 0.02 & 0.14 & 0.09 & 42.76 & 545 & 99.57 \\
\hline & 6 & 1.50 & 0.63 & 0.28 & 53.6 & 0.36 & 0.06 & 0.03 & 0.21 & 0.09 & 42.93 & 630 & 99.71 \\
\hline & 5 & 1.27 & 0.27 & 0.18 & 52.9 & 0.82 & 0.03 & 0.01 & 0.18 & 0.09 & 43.20 & 685 & 98.96 \\
\hline & 4 & 1.20 & 0.29 & 0.22 & 53.2 & 0.92 & 0.07 & 0.02 & 0.15 & 0.07 & 43.11 & 710 & 99.26 \\
\hline & 3 & 0.39 & 0.13 & 0.25 & 55.1 & 0.25 & 0.10 & 0.01 & 0.09 & 0.05 & 43.28 & 560 & 99.69 \\
\hline & 2 & 1.41 & 0.42 & 0.49 & 52.5 & 0.32 & 0.27 & 0.02 & 0.32 & 0.13 & 43.10 & 600 & 98.99 \\
\hline & 1 & 9.24 & 2.24 & 1.58 & 46.9 & 0.52 & 0.00 & 0.26 & 0.26 & 0.17 & 38.50 & 730 & 99.68 \\
\hline & Average & 2.25 & 0.61 & 0.45 & 52.5 & 0.67 & 0.18 & 0.04 & 0.19 & 0.10 & 42.53 & 656.8 & 99.54 \\
\hline
\end{tabular}


Table 2 (continued)

\begin{tabular}{|c|c|c|c|c|c|c|c|c|c|c|c|c|c|}
\hline Section & $\begin{array}{l}\text { Oxide } \\
(\%) \\
\text { Sample No }\end{array}$ & $\mathrm{SiO}_{2}$ & $\mathrm{Al}_{2} \mathrm{O}_{3}$ & $\mathrm{Fe}_{2} \mathrm{O}_{3}$ & $\mathrm{CaO}$ & $\mathrm{MgO}$ & $\mathrm{SO}_{4}$ & $\mathrm{~K}_{2} \mathrm{O}$ & $\mathrm{Na}_{2} \mathrm{O}$ & $\mathrm{Cl}^{-}$ & L.O.I & $\begin{array}{l}\mathrm{Sr} \\
(\mathrm{ppm})\end{array}$ & $\begin{array}{l}\text { Total } \\
(\%)\end{array}$ \\
\hline \multirow[t]{11}{*}{ Qattamiya } & 10 & 5.37 & 0.52 & 2.25 & 47.7 & 0.70 & 0.47 & 0.20 & 0.94 & 0.07 & 40.95 & 750 & 99.20 \\
\hline & 9 & 0.33 & 0.01 & 0.01 & 55.1 & 0.35 & 1.26 & 0.01 & 0.07 & 0.06 & 42.22 & 610 & 99.39 \\
\hline & 8 & 0.87 & 0.19 & 0.17 & 54.7 & 0.60 & 0.52 & 0.01 & 0.10 & 0.06 & 42.67 & 670 & 99.88 \\
\hline & 7 & 0.08 & 0.04 & 0.08 & 55.4 & 0.80 & 0.34 & 0.01 & 0.02 & 0.06 & 42.69 & 605 & 99.55 \\
\hline & 6 & 0.23 & 0.09 & 0.09 & 52.9 & 2.13 & 0.37 & 0.01 & 0.04 & 0.06 & 43.04 & 630 & 98.92 \\
\hline & 5 & 1.11 & 0.12 & 0.17 & 51.8 & 2.78 & 0.10 & 0.01 & 0.33 & 0.23 & 43.16 & 645 & 99.82 \\
\hline & 4 & 0.83 & 0.06 & 0.04 & 54 & 1.46 & 0.15 & 0.01 & 0.24 & 0.13 & 42.40 & 610 & 99.30 \\
\hline & 3 & 1.59 & 0.01 & 0.03 & 49.2 & 0.50 & 0.17 & 0.02 & 1.79 & 2.09 & 43.73 & 680 & 99.10 \\
\hline & 2 & 3.69 & 0.05 & 0.15 & 50.9 & 0.74 & 0.19 & 0.01 & 0.24 & 0.13 & 43.49 & 725 & 99.55 \\
\hline & 1 & 3.08 & 0.68 & 0.35 & 50 & 0.93 & 0.07 & 0.11 & 0.34 & 0.32 & 43.23 & 670 & 99.10 \\
\hline & Average & 1.71 & 0.17 & 0.33 & 52.2 & 1.09 & 0.36 & 0.04 & 0.41 & 0.32 & 42.75 & 659.5 & 99.38 \\
\hline
\end{tabular}

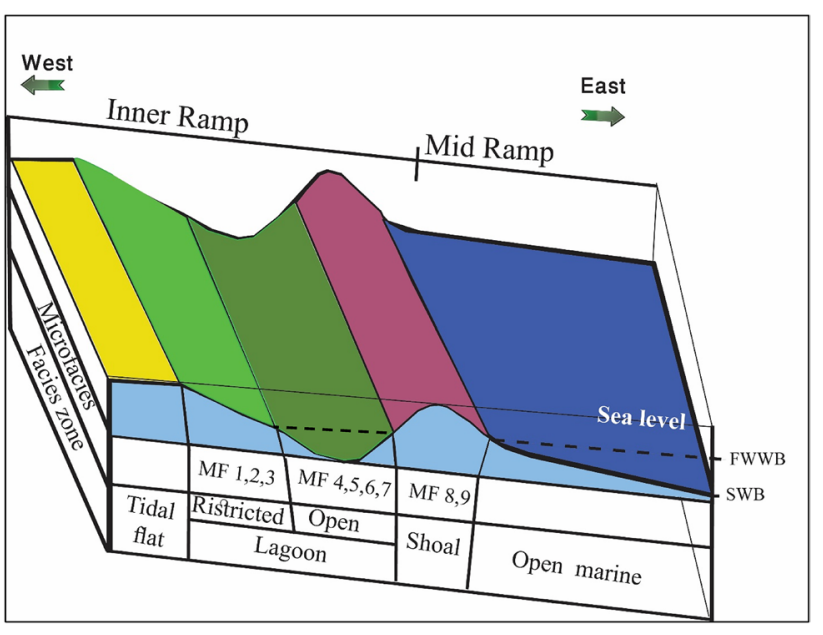

Fig. 8 Depositional model for the Qurn formation

18-FOR assigned by Flügel (2004) and can be deposited in a restricted inner ramp environment (Facies Zone 8 of Wilson 1975). In general, shallow nearshore and lagoonal environments, down to about $50 \mathrm{~m}$, are characterized by porcelaneous miliolid foraminifera. Planktonic foraminifera are absent or rare in shallow-marine environments. The restricted Platform (FZ 8) is less well connected with the open ocean, causing large variations in salinities and temperatures. It is characterized by shallow-water biota of reduced diversity, but commonly with a high number of individuals. Typical are miliolid foraminifera, ostracods, gastropods, algae, and cyanobacteria. The common lithofacies in this facies zone are lime-mudstone, wackestone, grainstone, and bindstone. The Lower and Middle Eocene shallow inner-platform areas were inhibited by low-diversity small miliolinids as well as larger alveolinids and discocyclinids. (Flügel 2004; Sallam et al. 2015a).

At several intervals of the studied Abu Shama section, the rich-miliolid grainstone and packstone microfacies types can be recorded and reflect a restricted inner ramp depositional environment. These protected shallow-marine facies are changed into molluscan and echinoid grainstone and rudstone microfacies that can be deposited in an open lagoon environment. The abrupt change from restricted to open lagoon microfacies and again to restricted platform environments indicates the oscillation in sea-level eustasy during the deposition of this formation. This highly pulsating seismicity in the study area is essentially related to the Suez Gulf rifting that initiated in the Jurassic and continued to the Late Miocene (Khalil and McClay 2001; Bignot and Strougo 2002; Issawi and Osman 2002; Bosworth et al. 2005; Tueckmantel et al. 2010; Selim 2011).

The studied Ghreibun section is characterized by enrichment of molluscan and nummulite fragments as well as medium to fine sand-quartz grains (FT9, FT10) that reveals its deposition in shoal zone (Sallam et al. 2015a; Wanas 2008; Wanas et al. 2020). These shoal carbonate microfacies are changed in several intervals into the open lagoon and restricted inner ramp facies associations. These dramatic changes are controlled mainly by sea-level eustasy and tectonic events.

Sallam et al. (2015b) described the microfacies association in the Qurn Formation and pointed out that, the microfacies types and the wide occurrence of various ostracod species in this formation indicate its deposition in high energy, shallow marine, most probably in shelf lagoon and reef environment. The formation was deposited in a shallowing-upward cycle starting at the base with the 
wackestone microfacies and ends by shelly Nummulitic grainstone and the water depths are some meters.

The variation curve of the $\mathrm{CaO}$ with $\mathrm{MgO}$ shows slightly reversible deviation due to $\mathrm{MgO}$ is mainly related to diagenetic processes as dolomitization of this rock unit (FT2) rather than the primary depositional environment. It can reflect a stage of marine regression and/or tectonic activity. The dolomitization process in limestone rocks increases as a result of the presence of these rocks near the air-water surface.

The vertical distribution of $\mathrm{Sr}$ element through the studied samples matches, slightly, with the distribution of $\mathrm{SiO}_{2}$ as noted in the studied sections. This can reflect the positive relation between $\mathrm{Sr}$ and $\mathrm{SiO}_{2}$. On the other hand, the $\mathrm{Sr}$ content has a negative relation with $\mathrm{CaO}$ in these samples. The high $\mathrm{Sr}$ concentrations are detected in both restricted lagoon and shoal associations microfacies, thus may be related to the warm environmental conditions. However, the middle Eocene climatic optimum is a global warming event which temporarily interrupted the longterm cooling trend initiated at the end of the early Eocene (Galazzo et al. 2014).

The high $\mathrm{Na}_{2} \mathrm{O}$ and $\mathrm{Cl}$ contents in the studied microfacies types (FT1, FT2, and FT3) reflect the deposition of these microfacies in high salinity marine conditions. Most foraminifera are found in water with a normal marine salinity of $35 \%$ and their diversity decreases with decreasing salinity. High carbonate concentrations in hypersaline marine waters favor the occurrence of porcelaneous Miliolina (Flügel 2004). The enrichment of $\mathrm{SiO}_{2}$ in these studied microfacies, specially FT1, is mainly related to the diagenesis processes rather than syn-sedimentary depositional conditions. The petrographical examination pointed out the developing of borrowing, as diagenetic biological activity, and the filling of these borrows by very fine quartz grains. The high $\mathrm{Fe}_{2} \mathrm{O}_{3}$ concentration in FT2 at the upper part of the Gharbiun section reflects the deposition of this microfacies type in shallower and high oxidation conditions.

The high $\mathrm{CaO}$ content in the studied open lagoon association microfacies (FT4, FT5, FT6, and FT7) is mainly related to organic carbonates productivity. High biological diversity in these microfacies has been recorded in the petrographical investigation. On the other hand, the concentration of $\mathrm{Na}_{2} \mathrm{O}$ and $\mathrm{Cl}$ in these microfacies is lower than that in the restricted lagoon microfacies (FT1, FT2 and FT3) and can reflect that the open lagoon microfacies are deposited in open circulation marine conditions.

The studied shoal microfacies have high $\mathrm{SiO}_{2}$ content that belongs to the detrital quartz grains as recorded in the microscopic examination. The slightly high concentration of $\mathrm{Na}_{2} \mathrm{O}, \mathrm{Fe}_{2} \mathrm{O}_{3}$ in FT9 at the uppermost part of the Qattamiya section revealed the shallower and oxidation depositional conditions.
The Bartonian rocks at Gebel Ramliya, east of the studied area, are dominated by coralline and marly limestone, including corals, bivalves, gastropods, echinoids and calcareous algae. In west-central Sinai, the Qurn Formation is equivalent to the Khaboba Formation which is composed mainly of yellow green, yellow brown soft fissile shales intercalated with greyish white moderately hard argillaceous limestone with rare pelecypods (Morsi et al. 2016). These hemipalgic facies of planktonic foraminiferal marl and limestone are deposited in inner to outer neritic shelf (Wanas et al. 2020). These facies are changed laterally towards the Jordan to Wadi Shalalla Formation which consists of foraminiferal limestone of middle to outer shelf (Farouk et al. 2013). Westward, the Bartonian rocks have been changed laterally at Minqar el Rayan area, southwest Fayoum, and represented by thick-bedded limestone with Nummulites spp., bivalve shells and bryozoan bands at base, followed upward by clastic sediments. The correlation of Bartonian rocks revealed the dominance of inner neritic depositional environments that represented by tidal flat and lagoonal facies in Fayoum area, lagoonal and shoal facies in Cairo area, and reefal facies in north Eastern Desert (Sallam et al. 2015a; Tawfik et al. 2016). These lithofacies became deeper eastward and represented by inner-middle neritic facies in Sinai and outer neritic facies Jordon. This gradual change can reflect carbonate ramp as a depositional model of the studied Qurn Formation (Fig. 8).

\section{Conclusions}

The lower part of the studied Qurn Formation in Qattamiya section is characterized by enrichment of miliolid, echinoids, and larger foraminiferal tests of Nummulites sp with rare planktonic foraminifera revealing a restricted inner ramp depositional environment. Besides, the main carbonate texture of this stratigraphic section is the packstone and reflects quite marine depositional conditions. On the other hand, the upper part of this section is made up of carbonates with echinoid and quartz grains with grainstone texture that is deposited in a shoal or sandy shoal depositional environments.

At the studied Abu Shama section, the Qurn Formation is composed of miliolid grainstone and packstone microfacies that reflect a restricted inner ramp depositional environment. These protected shallow-marine facies are changed into molluscan, and echinoid grainstone, and rudstone microfacies that can be deposited in an open lagoon environment. This dramatic change from restricted to open lagoon microfacies and again to restricted platform environments indicates the oscillation in sea-level eustasy, which may have related to the Suez Gulf rifting.

The bioclastic allochems in the Qurn Formation at the Ghreibun section revealed the deposition in the shoal build 
up zone. These shoal carbonate microfacies are changed in several intervals into open lagoon and restricted inner ramp facies types due to the sea-level eustasy and tectonic events. All the detected inner ramp microfacies associations of the Qurn Formation are changed eastward to mid-ramp in Sinai and outer ramp facies associations in Jordon.

The contrast vertical distribution of both $\mathrm{CaO}$ and $\mathrm{MgO}$ reflects that $\mathrm{MgO}$ is related mainly to the dolomitization process due to marine regression and/or tectonic activity. The distribution of $\mathrm{Sr}$ is similar to that of $\mathrm{SiO}_{2}$ in the restricted lagoon and shoal associations microfacies, thus may be related to the warm environmental conditions.

Funding Open access funding provided by The Science, Technology \& Innovation Funding Authority (STDF) in cooperation with The Egyptian Knowledge Bank (EKB).

Open Access This article is licensed under a Creative Commons Attribution 4.0 International License, which permits use, sharing, adaptation, distribution and reproduction in any medium or format, as long as you give appropriate credit to the original author(s) and the source, provide a link to the Creative Commons licence, and indicate if changes were made. The images or other third party material in this article are included in the article's Creative Commons licence, unless indicated otherwise in a credit line to the material. If material is not included in the article's Creative Commons licence and your intended use is not permitted by statutory regulation or exceeds the permitted use, you will need to obtain permission directly from the copyright holder. To view a copy of this licence, visit http://creativecommons.org/licenses/by/4.0/.

\section{References}

Abul Nasr RA, Hamza FH, Zaki NM (1993) Facies analysis and sedimentary environments of the middle-upper Eocene rocks in Sad Naam-Wadi Ramliya area, North Eastern Desert. Egypt Bull Fac Sci Al Azhar Univ Cairo 4(2):433-454

Adabi MH, Zohdi A, Ghabeishavi A, Amiri-Bakhtiyar H (2008) Applications of nummulitids and other larger benthic foraminifera in depositional environment and sequence stratigraphy: an example from the Eocene deposits in Zagros Basin. SW Iran Facies $54: 499-512$

Barron T (1907) The topography and geology of the district between Cairo and Suez. Egypt Surv Dept, Cairo, p 133

Bassi D, Nebelsick JH, Pugaernabéu Á, Luciani V (2013) Middle Eocene Nummulites and their offshore re-deposition: a case study from the middle Eocene of the Venetian area, northeastern Italy. Sed Geol 297:1-15

Bignot G, Strougo A (2002) Middle Eocene benthic foraminiferal assemblages from eastern Egypt, as biochronological et peritethyan lagoonal indicators. Rev Micropaleontol 45(2):73-98

Bosworth W, Huchon P, McClay K (2005) The Red Sea and Gulf of Aden basins. J Afr Earth Sci 43:334-378

Boukhary M, Hussein AI, El-Morcey IA (2002) Eocene larger foraminifera from Helwan, Greater Cairo. Egypt Rev Micropaleontol (paris) 45(1):27-47

Conoco (1987) A geological map of Egypt-1; 500 000, sheet Cairo.

Dunham RJ (1962) Classification of carbonate rocks according to depositional texture. In: Ham WE (ed) Classification of carbonate rocks, vol 1. AAPG Memorial, Tulsa, pp 108-121
El-Dosoky HM, Shahin TM (2020) Characteristics of lava-sediments interactions during emplacement of mid-Tertiary volcanism, Northeastern Desert, Egypt: field geology and geochemistry approach. Arab J Geosci 13(9):1-15

El Safori YA, Zalat AA, Eweda SA, Maih AM (1997) Eocene facies and bryozoans of the Qattamia area. Egypt J Geol Egypt 41(2A):365-425

Farag IM, Ismail MM (1959) A contribution to the structure of the area east of Helwan. Egypt J Geol 3:71-86

Farouk S (2015) Upper Cretaceous sequence stratigraphy of the Galala Plateaux, western side of the Gulf of Suez. Egypt Mar Pet Geol 60:136-158

Farouk S, Ahmad F, Smadi A (2013) Stratigraphy of the middle Eocene-lower Oligocene successions in northwestern and eastern Jordan. J Asian Earth Sci 73:396-408

Flügel E (1982) Microfacies analysis of limestones, 1st edn. SpringerVerlag, Berlin, p 648

Flügel E (2004) Microfacies of carbonate rocks: analysis interpretation and application. Springer-Verlag, Berlin, p 976

Galazzo BF, Thomas E, Pagani M, Warren C, Luciani V, Giusberti L (2014) The middle Eocene climatic optimum (MECO): a multiproxy record of paleoceanographic changes in the southeast Atlantic (ODP Site 1263, Walvis Ridge). Paleoceanography 29:1143-1161

Ghobrial AC (1971) Geological studies in the area east of Maadi, U.A.R. M. Sc. Thesis Fac. Sci., Cairo Univ. Egypt, p 114

Gilham RF, Bristow CS (1998) Facies architecture and geometry of a prograding carbonate ramp during the early stages of foreland basin evolution: lower Eocene sequences, Sierra del Cadí, SE Pyrenees, Spain. Geol Soc Lond Spec Publ 149:181-203

Hadi M, Mosaddegh H, Abbassi N (2016) Microfacies and biofabric of nummulite accumulations (Bank) from the Eocene deposits of Western Alborz (NW Iran). J Afr Earth Sc 124:216-233

Hagag W (2016) Structural evolution and Cenozoic tectonostratigraphy of the Cairo-Suez district, north Eastern Desert of Egypt: Fieldstructural data from Gebel Qattamiya-Gebel Um Reheiat area. J Afr Earth Sc 118:174-191

Hottinger L (1997) Shallow benthic foraminiferal assemblages as signals for depth of their deposition and their limitations. Bull Soc Geol Fr 168:491-505

Ismail MM (1956) The area East of Helwan, a detailed geological survey scale 1:25,000: Ph.D. Thesis, Cairo University, Egypt.

Ismail MM, Farag IAM (1957) Contribution to the stratigraphy of the area to the east of Helwan. Bull. Inst. Desert, Egypt, pp 95-134

Issawi B (2002) Egypt during the Phanerozoic. Geol. Arab World, Cairo Univ., 6th Int. Conf (2):401-450

Issawi B (2005) Archean-Phanerozoic birth and development of the Egyptian land. 1st int. Conf. Geol Tethys Cairo Univ., 2(380): 380-380.

Issawi B, Osman R (2002) Geological history of NE Egypt during the Paleozoic and Mesozoic as anticipated from lithofacies isopach maps. Geol. Arab World, Cairo Univ., 6th Int. Conf. II: 451-468

Issawi B, El-Hennawi M, Mazhar A (1999) The Phanerozoic geology of Egypt: a geodynamic approach. Geol Surv Egypt 76:462p

Issawi B, Francis M, Youssef A, Osman R (2009) The Phanerozoic of Egypt: a geodynamic approach. Geol Surv Egypt 81:589

Khalil SM, McClay KR (2001) Tectonic evolution of the NW Red Sea-Gulf of Suez rift system. In: Wilson RCL, Whitmarsh RB, Taylor B, Froitzheim N (Eds) Non-volcanic rifting of continental margins: a comparison of evidence from land and sea. Geol Soc Lond 187:453-473

Maurice TE (2001) Sedimentary petrology: an introduction to the origin of sedimentary rocks, 3rd edn. Blackwell Science Ltd Editorial Offices, United Kingdom, p 262 
Morsi AM (1991) Stratigraphic and ecologic evaluations of the Eocene rocks in the area south west of the Cairo Suez raod. M. Sc. Thesis, Geol. Fac Sci Ain Shams Univ., Cairo, 205p.

Morsi AM, Hewaidy AA, Samir A (2016) New marine Ostracod species from the middle Eocene of West-Central Sinai, Egypt. J Afr Earth Sci 117:150-159

Moustafa AR, Abd-Allah AMA (1991) Structural setting of the central part of the Cairo- Suez district, -Mid East Res. Cent., Ain Shams Univ., Sc. Res. Ser (5):133-145

Nasief MS, Korin AE (2018) Middle-upper Eocene Benthic Foraminiferal Biostratigraphy across Cairo-Sukhna district, North Eastern Desert Egypt. J Appl Geol Geophys 6(1):43-53

Osman R (2003) New findings in the Eocene stratigraphy of Gebel Ataqa-Northern Galala, North Eastern Desert. Egypt J Sedi Egypt 11:95-109

Patton TL, Moustafa AR, Nelson RA, Abdine SA (1994) Tectonic evolution and structural setting of the Suez Rift. Am Assoc Pet Memoir 59:9-55 (In interior Rift Basins. (ed. S. M. London))

Racey A, Bailey HW, Beckett D, Gallagher L, Hampton M, McQuilken J (2001) The petroleum geology of the early Eocene El Garia formation, Hasdrubal Field, Offshore Tunisia. J Pet Geol 24:29-53

Said R (1962) The geology of Egypt. Elsevier, Amesterdam, p 377

Said R (1990) The geology of Egypt. Balkema, Amesterdam, p 734

Sallam E, Wanas HA, Osman R (2015a) Stratigraphy, facies analysis and sequence stratigraphy of the Eocene succession in the Shabrawet area (north Eastern Desert, Egypt): an example for a tectonically influenced inner ramp carbonate platform. Arab J Geosci 8:10433-10458

Sallam E, Issawi B, Osman R (2015b) Stratigraphy, facies and depositional environments of the Paleogene sediments in Cairo-Suez district. Egypt Arab J Geosci 8:1939-1964

Santanu B, Khanolkar S, Kumar PS (2018) Facies and depositional settings of the Middle Eocene-Oligocene carbonates in Kutch. Geodin Acta 30(1):119-136

Selim SS (2011) Paleoenvironmental modeling and paleogeography for the Upper Senonian-Paleogene sequences, north of the Gulf of Suez, Egypt with especial emphasis on the red beds. Ph. D. Thesis, Cairo Univ., Giza, Egypt, p 350

Steckler M, Berthelot F, Lyberis N, Le Pichon X (1988) Subsidence in the Gulf of Suez implications from rifting and plate kinematics. Tectonophysics 153:249-270
Strougo A (1985) Eocene stratigraphy of the eastern Greater Cairo (Gebel Mokattam-Helwan) area. Earth Sci Ser 5:1-39 (M.E.R.C. Ain Shams Univ)

Strougo A, Abdallah AM (1990) Mokattamian stratigraphy of northcentral Eastern Desert (south of Maadi-Qattamiya road). Earth Sci Ser 4:152-175 (M.E.R.C., Ain Shams Univ.)

Strougo A, Boukhary MA (1987) The middle Eocene-upper Eocene boundary in Egypt: present state of problem. Rev Micropaleontol 30:122-127

Strougo A, Bignot G, Abdallah AM (1992) Biostratigraphy and paleoenvironments of the Middle Eocene benthic foraminiferal assemblages of north central Eastern Desert, Egypt. Earth Sci Ser 6:1-12 (M.E.R.C., Ain Shams Univ.)

Tawfik M, El-Sorogy A, Moussa M (2016) Metre-scale cyclicity in Middle Eocene platform carbonates in northern Egypt: implications for facies development and sequence stratigraphy. J Afr Earth Sc 119:238-255

Tueckmantel C, Fisher QJ, Knipe RJ, Lickorish H, Khalil SM (2010) Fault seal prediction of seismic-scale normal faults in porous sandstone: a case study from the eastern Gulf of Suez rift. Egypt Mar Petrol Geol 27:334-350

Vaziri-Moghaddam H, Kimiagari M, Taheri A (2006) Depositional environment and sequence stratigraphy of the Oligo-Miocene Asmari Formation in SW Iran. Facies 1:41-51

Wanas HA (2008) Cenomanian rocks in the Sinai Peninsula, Northeast Egypt: Facies analysis and sequence stratigraphy. J Afr Earth Sc 52:125-138

Wanas HA, Abu Sham AM, El-Nahrawy SA (2020) Depositional model and sequence stratigraphy of the Paleocene-Lower Eocene succession in the Farafra Oasis, Western Desert Egypt. J Afr Earth Sci 162:103706

Wilson JL (1975) Carbonate facies in geologic history. Springer, New York, $\mathrm{p} 471$

Youssef MI (1968) Structural pattern of Egypt and its interpretation. Am Asso Petrol Geol Bull 52:601-614

Publisher's Note Springer Nature remains neutral with regard to jurisdictional claims in published maps and institutional affiliations. 